\title{
Sprawozdanie z XII Międzynarodowej konferencji z cyklu „Ekologia humanistyczna” pt. „Kościół wobec kryzysu ekologicznego. W 30. rocznicę Listu Pasterskiego Episkopatu Polski nt. Ochrony środowiska" (Warszawa, 16.05.2019)
}

\author{
Report on the $12^{\text {th }}$ Conference in "Humanistic Ecology" Series: "The Church towards Ecological \\ Crisis. On the 3oth Anniversary of Polish Bishops' Pastoral Letter on Environmental Protection" \\ (Warsaw, 15 May 2019)
}

\author{
Grzegorz Embros \\ Centrum Ekologii i Ekofilozofii, Uniwersytet Kardynała Stefana Wyszyńskiego w Warszawie \\ ORCID: https://www.orcid.org/0000-0003-0861-6291・g.embros@uksw.edu.pl
}

Konferencja została zorganizowana przez Instytut Ekologii i Bioetyki Uniwersytet Kardynała Stefana Wyszyńskiego w Warszawie przy współpracy Ruchu Ekologicznego św. Franciszka z Asyżu (REFA) oraz Światowego Ruchu Katolików na rzecz Ochrony Środowiska. Patronat honorowy sprawowali Minister Środowiska oraz Przewodniczący Konferencji Episkopatu Polski. Podczas obrad przyjęto przez aklamację Apel chrześcijan i ludzi dobrej woli w Polsce o poszanowanie dzieła stworzenia.

Po powitaniu uczestników przez dyrektora biura rektorskiego ks. dra Zenona Hanasa SAC, słowie wstępnym organizatorów i honorowych patronów sympozjum głos zabrał ks. prof. Joshtrom Isaac Kureethadam, który przedstawił referat wprowadzający w tematykę konferencji zatytułowany „Rola ludzi dobrej woli w kwestii ekologicznej w wypowiedziach papieża Franciszka". Przedstawił w nim stanowisko Papieża dotyczące ochrony stworzenia i piękna stworzonego świata przekładające się na poszanowanie każdego stworzenia Bożego oraz środowiska, w którym żyjemy. Wyrażają to, przytoczone w wystąpieniu, słowa modlitwy Papieża o zachowanie Chrystusa w naszym życiu, tak abyśmy mogli chronić innych, tak abyśmy mogli chronić stworzenie. Autor referatu przypomniał zaproszenie, jakie papież Franciszek kieruje w encyklice Laudato si' do Kościołów, religii i wszystkich ludzi dobrej woli, aby troszczyć się o wspólny „kruchy ziemski dom", zanim będzie na to za późno. W tym kontekście, autor wystąpienia, przywołał różnego rodzaju zagrożenia związane z zanieczyszczeniem oceanów, zmianami klimatycznymi, zanieczyszczeniami chemicznymi czy utratą bioróżnorodności. W swoim wystąpieniu ks. prof. Joshtrom Isaac Kureethadam zaakcentował za encykliką, że pierwszymi i największymi ofiarami kryzysu ekologicznego są biedni, którzy w najmniejszym stopniu przyczynili się do tego kryzysu. Przywoływał liczne przykłady obrazujące 
taką sytuację i podkreślał, że Laudato si’ jest $\mathrm{w}$ istocie encykliką społeczną, a nie encykliką na temat zmian klimatu. Zwrócił następnie uwagę na duchowe źródła kryzysu. Kryzys ekologiczny jest przejawem głębokiego kryzysu duchowego (religijnego). Odniósł się także do kwestii ekonomicznych i politycznych. Podkreślił słabość obecnego paradygmatu ekonomicznego prowadzącego do niszczenia planety. Nawiązując do księgi rodzaju, ukazał, że panowanie człowieka nad resztą stworzenia nie może być przejawem absolutnej i bezwzględnej władzy nad tym stworzeniem. Przypomniał przy tym, że polityka jest pracą dla wspólnego dobra. Wobec tego polityka i ekonomia nie moga być zdominowane przez myślenie krótkoterminowe w perspektywie szybkiego zysku (wyzysku) czy wygranych wyborów (zdobycia władzy). W tym kontekście istotną rolę będą odgrywać ludzie dobrej woli, a szczególna nadzieja pokładana jest w ludziach młodych, wykazujących wrażliwość na kwestie środowiskowe czy cierpienie wykluczonych, żądających zmiany obecnego stanu rzeczy. Prelegent podkreślił również, że szczególną troską winny być objęte społeczności pierwotne (rodzime) wraz z ich tradycjami. Nawiązał przy tym do postanowień synodu „Amazonia: nowe ścieżki dla Kościoła i ekologii integralnej" (8.06.2018). $\mathrm{Na}$ zakończenie ks. prof. Joshtrom Isaac Kureethadam przypomniał stanowisko papieża Franciszka dotyczące roli (udziału) Kościołów i społeczności chrześcijańskich oraz innych religii w podejmowaniu wysiłków na rzecz przeciwdziałania nieodpowiedzialnej eksploatacji naszej planety. Odwoławszy się do zdolności człowieka do wznoszenia się ponad swoje partykularne interesy i umiejętności poświęcenia się sprawom wyższej rangi, zakończył wystąpienie wezwaniem do podejmowania działań na rzecz ochrony środowiska, pamiętając także o przyszłych pokoleniach.

Drugi referat pt. „Dialogiczny i mediacyjny potencjał ekologii integralnej" zaprezentował o. dr Stanisław Jaromi. Odwołał się w nim do encykliki Laudato si' w sposób syntetyczny ujmującej refleksję nad głównymi zagadnieniami ekologii, ochrony przyrody i ochrony klimatu, prezentującej nową perspektywę dla aktywności ekologicznej w świetle zasad ekologii integralnej. Zwrócił uwagę, że w wielu miejscach świata encyklika ta stała się punktem odniesienia dla katolików w kontekście kryzysu ekologicznego. Podkreślił, że prezentuje ona perspektywę religijną i duchową, pokazuje konkretne przykłady stylu życia jednocześnie ekologicznego i chrześcijańskiego. Szczególną uwagę zwrócił o. Jaromi na piąty rozdział tego dokumentu, w którym zarysowana została koncepcja dialogu niosącego nadzieję na porzucenie spirali autodestrukcji, w jakiej pogrąża się ludzkość. Zawiera się tam również pozytywna propozycja - koncepcja humanizmu komunikacyjnego. Jego mechanizmy, czyli działania restytuujące wartości i kreujące wspólnotę, stanowią podstawy dialogu. Fundamentem prezentowanego programu jest personalizm i hermeneutyka chrześcijańska, a jego celem Kościół zainteresowany światem i jego problemami, który dołącza do głosu tych wszystkich, którzy protestują przeciw niszczeniu Ziemi i jej nieodpowiedzialnej eksploatacji.

Trzeci referat dotyczący roli argumentacji religijnej w kształtowaniu proekologicznych postaw chrześcijan w Polsce wygłosił ks. Ryszard F. Sadowski, prof. UKSW. Zwrócił uwagę, że argumenty religijne stanowią ważny czynnik wpływający na codzienne wybory ludzi. Wybory te mają swoje konsekwencje między innymi dla środowiska przyrodniczego i przyczyniają się do polepszenia lub pogorszenia jego stanu. Autor referatu ukazał ekologiczny potencjał tkwiący w argumentacji religijnej Polaków. Przedstawił argumenty wynikające z wyznawanej wiary stosowane w kontekście kwestii ekologicznych. Zaprezentował także argumentację religijną obecną w wypowiedziach oficjalnych przedstawicieli Kościoła katolickiego w Polsce na tematy środowiskowe. Uzupełnienie wypowiedzi prelegenta stanowiły przykłady motywowanych religijnie działań świeckich chrześcijan na rzecz środowiska. 
Część druga konferencji obejmowała sześć referatów. Pierwszy z nich „Ekologiczne inicjatywy Kościoła na Górnym Śląsku” wygłosił ks. dr Witold Kania, przedstawiając najważniejsze inicjatywy ekologiczne wskazane w tytule wystąpienia. Prezentacja ta stanowiła punkt wyjścia do zasadniczej tematyki wystąpienia, którą było odczytanie encykliki Laudato si' w kontekście zagadnienia postępu. Autor wskazał na dobre i złe strony postępu oraz obecne w encyklice odniesienia związane ze sformułowaniami: „irracjonalna wiara w postęp” i „mit nieograniczonego postępu materialnego". Zarysował dzieje idei postępu oraz wskazał filozoficzne kryterium służące do jego oceny. Prelegent poddał krytycznej analizie paradygmat technokratyczny ucieleśniający fałszywe oblicze postępu, w którego ramach postęp ma charakter konieczny i nieograniczony. Stawiając w centrum człowieka, żyjącego według relatywistycznej zasady „użyj i wyrzuć”, powoduje on w skali globalnej kryzys ekologiczny, duchowy i kulturowy. Dalsza część wystąpienia poświęcona była proponowanemu przez papieża Franciszka nowemu modelowi postępu, który charakteryzuje wymiar wertykalny i horyzontalny. Jego owocem ma być indywidualna troska o ubogich oraz większa sprawiedliwość pomiędzy narodami. Nie można go osiągnąć bez zmiany mentalności (nawrócenia) oraz konkretnych decyzji indywidualnych i politycznych.

Cecilia Dall'Oglio zaprezentowała wystąpienie „Ekologiczne inicjatywy Global Catholic Climate Movement". W referacie przedstawiła strukturę i główne założenia Światowego Ruchu Katolików na Rzecz Środowiska (GCCM). Jest to organizacja o zasięgu międzynarodowym, promująca wartości ekologiczne wśród katolików. Autorka wystąpienia zwróciła uwagę na ścisły związek między nauczaniem Kościoła katolickiego a troską o stworzenie. Podkreśliła, nawiązując do encykliki papieża Franciszka Laudato si', że wysiłki mające na celu zapobieganie skutkom zmian klimatu są uznawane za ważną misję ludzi wierzących. Cecilia Dall’Oglio zwróciła uwagę na istnienie trzech głównych wymiarów opisujących sposoby wprowadzenia nauczania Papieża w życie. Należą do nich: wymiar duchowy, wymiar stylu życia i wymiar polityki publicznej. W referacie znalazło się wiele przykładów dobrych praktyk realizowanych od czasu utworzenia GCCM w 2015 r. oraz przedstawione zostało szczegółowe kalendarium prezentujące kluczowe osiągnięcia tej organizacji.

Trzeci referat wygłosili Weronika i Elgars Felcis. Nosił on tytuł: „Odpowiedź Kościoła w małym państwie na kryzys ekologiczny czy możliwa jest diecezja samowystarczalna energetycznie i neutralna klimatycznie? Szanse i wyzwania na przykładzie Diecezji Ryskiej”. Autorzy wystąpienia zaprezentowali czynniki historyczne i kontekstowe stanowiące - ich zdaniem - potwierdzenie, że Kościół rzymskokatolicki na Łotwie nie odgrywa znaczącej roli w ochronie środowiska ani w budowaniu świadomości ekologicznej w tym kraju. Prelegenci zauważyli jednak, że odpowiadając na wezwanie papieża Franciszka zawarte w encyklice Laudato si', poświęca się obecnie więcej miejsca na refleksję dotyczącą nawrócenia ekologicznego. Wykorzystując dostępne w domenie publicznej dane na temat zasobów Kościoła katolickiego na Łotwie, autorzy dokonali analizy możliwości i ograniczeń w zakresie wzmocnienia reakcji Kościoła na kryzys ekologiczny.

Kolejne wystąpienie zatytułowane „Szkoła liderów ekologii integralnej i inne inicjatywy Ruchu Ekologicznego Franciszka z Asyżu" zaprezentowała uczestnikom Emilia Ślimko. Autorka przedstawiła bogatą działalność Ruchu Ekologicznego św. Franciszka z Asyżu (REFA), działającego pod hasłem „katolicy wśród ekologów, ekolodzy wśród katolików”. Ruch ten powstał w środowisku polskich franciszkanów i od ponad 30 lat upowszechnia w Polsce potrzebę zaangażowania się chrześcijan w działania na rzecz ochrony środowiska. W swej działalności REFA podjął wiele różnych prośrodowiskowych inicjatyw i zrealizował wiele ekologicznych projektów. W referacie przedstawiono wybrane ich przykłady. 
Ks. dr Andrzej Lubowicki przedstawił wykład na temat młodego pokolenia katolików stającego wobec problemów ekologicznych na przykładzie inicjatyw Katolickiego Stowarzyszenia Młodzieży. Działa ono w ramach 41 diecezji Kościoła rzymskokatolickiego w Polsce i według danych z roku 2019 liczy ok. 20 ooo członków zrzeszonych w ok. 1000 oddziałach parafialnych i kołach środowiskowych. Wśród licznych aktywności podejmowanych przez KSM jest działalność na rzecz ochrony stworzenia. W wystąpieniu prelegent zaprezentował kilka najważniejszych projektów ekologicznych realizowanych przez to stowarzyszenie. Wśród nich znalazły się projekty: Bug, rzeka życia - edukacja dla młodzieży, młodzież dla ekorozwoju; Młodzi Tej Ziemi; Elektro Odpowiedzialni; Kajakowy Patrol św. Franciszka; Młodzi dla Środowiska; Środowisko Młodzieży.

Ostatni wykład w ramach tej sesji, dotyczący pozyskiwania funduszy z Narodowego Funduszu Ochrony Środowiska i Gospodarki Wodnej przez podmioty religijne na rzecz działań prośrodowiskowych, wygłosił Artur Michalski. Fundusz ten od 30 lat jest głównym źródłem finansowania inwestycji i innych działań proekologicznych w Polsce.
Prelegent przedstawił aktywność Funduszu w następujących obszarach: Ochrona i zrównoważone gospodarowanie zasobami wodnymi, wsparcie przedsięwzięć w zakresie niskoemisyjnej i zasobooszczędnej gospodarki, w tym innowacji; gospodarka odpadami; ochrona powierzchni ziemi, geologia i górnictwo; ochrona atmosfery, w tym poprawa jakości powietrza; ochrona różnorodności biologicznej; monitoring środowiska, przeciwdziałanie zagrożeniom środowiska; edukacja ekologiczna; ekspertyzy i prace naukowo-badawcze. NFOŚiGW wdraża również programy priorytetowe, wspierające działania służące ochronie środowiska, których beneficjentami mogą być organizacje kościelne. W tym kontekście zaproponował programy związane z edukacją ekologiczną, ochroną różnorodności biologicznej i krajobrazowej, budownictwa energooszczędnego oraz mające na celu zmniejszenie zużycia energii w budownictwie.

Konferencję zakończył panel z udziałem wszystkich prelegentów nt. efektu synergii ekologicznych działań Kościoła w Polsce. Zwieńczeniem obrad było przyjęcie przez aklamację „Apelu chrześcijan i ludzi dobrej woli w Polsce o poszanowanie dzieła stworzenia". 